\title{
The Importance of Alumni Association at University Level in Karachi, Pakistan
}

\author{
Anila Fatima Shakil, Waqar Un Nisa Faizi*
}

Department of Education, Jinnah University for Women Karachi, Pakistan

\begin{abstract}
The reputation of any educational institution depends upon good results, co-curricular activities, environment, and investments. But there is one factor which only requires support and encouragement and brings strength and expansion to the institution's reputation and progress and that factor is the alumni's of the Alma Mater. Due to "Alumni association" students feel obliged and honored to return the favors and successes as well as the Alma Mater also get benefit and grow enormously in terms of both academics and administration at national and international level. This study was based on survey method. From the population five universities were selected, where Alumni Associations exists. One Hundred and twenty respondents including 100 students and 20 teachers were randomly selected for the collection of data by using questionnaire method. Later on data were analyzed by \% method. Most of the respondent had a view that to grow and prosper all the other factors as well as Alumni Association plays an important role in terms of both academics and administrations.
\end{abstract}

Keywords Higher Education, Alumni Association, Career Guidance

\section{Introduction}

Education imparts learning to an individual so that he may have his own place in the society. Especially at higher level it direct individuals paramount mission which leads him to a successful life. According to V.C Pandey (2005) paramount mission of higher education is to serve the human person and society through its work of research and enquiry, its course of study and training, its co-operate activities and its partnership with various social areas, higher education make a key contribution to opening up and highlighting new path to a better future for society and individual. As we know that higher education is one of the major aspects of the development of any country so it is essential for our country to give quality education to our individuals at this level, as it also helps to get sustainability to our country. Dr. Isani, (2003) said that higher education is today recognized as a capital investment in human capital and this increase labor productivity, furthers technological innovational and produces a rate of return markedly higher them that of physical capital. Therefore every educational institute at this level is responsible for the development of the individual to the optimum level to enable him to lead a productive and happy life in the society. Not only has this but it also given helps in the development of skills, value and attitudes that helps to transform society towards a better social, economical and

* Corresponding author:

faizi5120@yahoo.com (Waqar Un Nisa Faizi)

Published online at http://journal.sapub.org/edu

Copyright (C) 2012 Scientific \& Academic Publishing. All Rights Reserved political order. For this purpose each institution not only maintains quality education with international standards but also establish number of association too. Now a-day we see that ruinous kids of association are established at higher level to run the institute in and extra ordinary manner. There are the organization in which member gather to support university and to develop and sustain strong ties between student and university although they may very in structure, leadership and level of activity. All successful organization relies on committed leaders and one of these organizations is alumni Association.

Alumni Association plays an important role in awaking the students about opportunities available in the market. When the students will remain in contact with the institute, they can create capacity for other student going behind them. It helps to over come unemployment from society. When the students pass out from their concern institute and occupy the vacancies in market, they can realize their frail areas of personality and then can inform the institute can arrange some steps to prepare students according to the need of society as well as desire of individual too. The students are provided with the information that where the chances are available with respect to their particular field and where the specialization is offered to their concerned areas. Alumni association is also responsible to arrange such kinds of activities and programs through which the students can keep in touch with their institution even after the completion of their studies. They get benefits from university and play effective roe for the upbringing of university.

Alumni Association often organize social events, publish news letters or magazines and raise funds for organization as 
well as help the students who are currently studying. Additionally, such groups often support new alumni and provide a forum to new friendship and business relationships with people of similar background and interest. Alumni Association are mainly organized around universities or department of universities but may also be arranged among students that studied in a certain country. It also helps out the students to be awarded about the facilities available within and outside the country, especially for those who want to move towards foreign countries for their advance education. As they can share their knowledge and skills but also enhance the relation among different institutes that how they are working and what are the plus points. It also enables them to introduce with the good qualities of their own institute and association at this level to others as well as to adopt their good characteristics also.

"Alumni Association is committed in spreading awareness of the importance of philanthropy, strengthening the bond between student and alumni. Its mission is to spearhead students philanthropy projects that help to bring campus wide understanding of the importance of service."

(http://www.xaiver.edu/sall)

The Alumni Association creates a space in which alumni can interact within a community of people who shared a unique experience. The Alumni Association's primary focus is to strengthen alumni, relations between students and its alumni, while promoting and considering the best interest of the institute.

"The Associations provide support to institute and for all alumni events including reunion and regional events and work with the career development and admission office as well as other campus units on matters of importance to alumni".

(http://www.haveford.edu/alumnirelations)

The Alumni association is human network that exist to promote the welfare of university, broaden and sustain friendship among alumni and stimulate alumni interest in network of clubs".

(http://alumni.jhu.edu./association /index.htm).

The Alumni association is beneficial for both students as well as institute. These associations promote interaction among alumni in area and provide new comers to the area with valuable social and professional contact. Membership also provides a new way for alumni to help each other as well as perusing their education and in stating their careers. All association members can derive satisfaction from developing and implementing program that promote their interest of any institute. Any person holds a degree of that institute is eligible for membership. The leadership role of association is not only to encourage and promote the enhancement, but also sustains loyalty and enthusiasm among students and institutes. "One of the vital roles of Alumni organization is to keep the Alumni office in formed of up to date address of the students. These are assisting in forwarding information concerning prominent alumni to the university's Alumni office. It is also necessary for intellectual stimulation, community services and social events. (http://www.bu.edu/alumni/int/connect/association.html)

Such associations also an effective role to make the students able to led a good life as it engage them or alumni in meaningful service. The members of alumni associations provide a helping hand to those who are currently studying and to those who need professional help from their seniors at their working places. Not only this but the committee of the alumni association organize annual career counseling seminars/ discussion / workshops for the student of final year which helps to select the appropriate fields which has proved to be very popular and useful for the students for their forth coming life.

Alumni Association also assists in developing financial and other resources for the institute. "It is a positive step in preserving and keeping the standard of the institute high. It fasters the tradition and growth of university or institute through social and related events arranged at university. It supports the university's educational mission, preserves its heritage, promotes its advancement and assist the university to achieve prominence and maintain its integrity.

(http://www.hamdard.edu.pk/alumni)

The alumni associations are committed to engage students throughout their academic career in order to form a stronger bond with the institute and its alumni body.

It is a key portfolio in supporting and managing student related matters outside the classroom. It analyzes the examination results, quality analysis of performance, monitoring high flyers and proposing remedial measures for week students.

(http://alumni.indiana.edu/career/index.shtmp)

The Alumni Associations provide enough guideline for the students to cope up with changes, hurdles and challenges of time. It also steers to adjust with educational as well as professional life and provides a good forum for the student to share their common knowledge and to be aware of new trends in their respective fields and society within and outside the country.

\section{Aims of Study}

1. To know how much Alumni Association helps in organizing social events to create the sense of social services among students.

2. To know how much it will helps out the students to share their common knowledge and effective in promoting employment among graduates.

3. To know how come it is beneficial to aware the students about opportunities available for further studies as well as in market.

4. To know how much it is advantageous in creating strong bond between students and institution.

5. To know how much it will be helpful to polish leadership and administrative qualities in students.

\section{Review of Related Literature}

Education makes its special contribution to train an indi- 
vidual to bring about change in his behavior, develop innate capacities and lead toward process of successful life. An individual becomes a responsible man towards society on receiving such training. Such training is possible only through education. To provide better education, various activities are offered by every institution especially at higher level. Researchers clearly show that colleges and universities can be extremely effective economic and social accelerate for both individual and entire societies. It promotes personal growth as well. Such education helps the student to perform well in his work, to be a good family member and help him to move forward. For this purpose different activities are run in every institution that supports the institute to work in an effective manner and to publicize its qualities at large. Such kinds of activities are accomplished by the Alumni Association.

According to http://answer.yahoo.com/question/index "a graduate of former student of a specific schools / colleges / university" and according to http://dictionary.sensagent.com a pupil, especially a graduate of a college or other seminary of learning"

Alumni reunions are popular events at many institutions. They are usually organized by alumni associations and are often social occasions for fund raising. Recently the concept of alumni has expanded to include people who have departed from any kind of organization or program. The Alumni Association provides a platform for the students for social and intellectual up gradation. It helps in the promotion of education as well as in the flow of knowledge. It does not play a role in local civic activities and community integration, but also faster all the essential elements of democracy in the institute. With the help of Alumni various program are held which help in maintaining long term relationships among the members and the institute. It provides a chance for the students to volunteer their time, expertise and well wishes for the promotion of institute. Due to such reasons the alumni association has been established everywhere in the top universities of world like McGill university of Canada, founded in 1821 and established its Alumni association in 1880. It offers many services to its graduates such as financial life, Health and Dental assurance etc. The Queen University founded in 1926, maintained its status as one of the top 10 universities in Canada. Queens in 2008, and it has developed from link between alumni and prominent leaders, which made it won the 2006 Award for 5 best career advisor network. The University of Cambridge is the $2^{\text {nd }}$ oldest university in English speaking world. It produces 83 Noble laureates to date, more then any university in the world. Its alumni run since 2003, according to Greek Law, was named HCAA (Hellenic Cambridge Alumni Association). Similarly the University of Alberta is one of the top 100 teaching and research universities \& it has more national awards winner then others in India. It created its Alumni in 1912 and automatically all graduates become life time members of its association As Alumni Association is very important for the upgrading of any institute and become a reason of reorganization of the university in the world of University.
Therefore, it is present at least in every institute of country, which has consistently maintained their positions, as the source of $1^{\text {st }}$ choice for a wide cross section of corporations, business and govt. agencies. Graduates coming out of outstanding universities of Pakistan over the last several decades have distinguished themselves as catalyst of progress for prominent, private and public organization in Pakistan and through out the world, such sort of alumni associations are also present in Karachi at tertiary level, like at Agha Khan University Karachi, NED university Karachi, Hamdard University Karachi, University of Karachi and Jinnah University for Women Karachi. It provide opportunity for volunteerism, development of relations between students and university, provision of information about different fields, admission and track of students, awareness about practical life, promotion of employment as well as the information about the market value of students. In our city, it is present in separate departments or it reflects the whole university. Some of famous universities and their Alumni are Alumni of Agha Khan University, established in 1993. The Alumni association operates for profit or pecuniary gain. It also help to those who left for USA / UK / Europe for post graduate training and to record career pathways of returning Alumni. Another Alumni is NED University Alumni Association which was formed in 2004 as loose network for encouraging promotions of Alumni related activities. This form enabled graduates of college or university to initiate their support and activities related to student welfare, academics and research. These activities have been extended to focus on Alumni relation and their efforts in support of institute. To extend the spirit of this alumni association, one conditional category of friends of alumni has been included in the network in addition to Alumni. Similarly the Hamdard University also established its alumni association named HUAA (Hamdard University Alumni Association) in 2008. HUAA will strive to promote a lasting relationship among alumni including friends and faculty through different occasions of the university. The Alumni association is important also in Academic institutes like in Karachi University and Jinnah University for Women. In both universities department base alumni's established in different years since they founded. Karachi University has many aims and missions related to its Department-Alumni Association such as to provide platform for alumni social and intellectual interaction, to faster all essential elements of democracy and integrate them in the institute, the association shall be not for profit organization, dedicated to providing a cohesive platform where number can interact and exchange ideas in open form and constructive atmosphere. Another university, Jinnah University for women, which is the first university for women in Pakistan, has also such kind of associations established in various departments in every faculty.

If any institute wants to publish its fame or to have a feedback of its services, the alumni association counts a lot. It is the need of modern education students, society as well as carry out the mission of university also. So it should be established in each institute and department, especially in our 
country.

\section{Research Methodology}

This is a discipline research in which deductive and inductive method was used. For this study five universities had been selected from all the universities of Karachi. Among these universities 20 teachers and 100 students were selected for the collection of data by using questionnaire method. In the questionnaire a brief detail of internal is asked about the importance of Alumni Association at higher level. The questionnaire filled from following universities:

1. Agha Khan University

2. Hamdard University

3. NED University

4. Karachi University

5. Jinnah University

Questionnaires were pretest and tables were also prepared. After the collection of data, simple percentage method has been used for the analysis of data.

\section{Results}

Table 1. shows the views of students about Alumni association, as its role in the promotion of students

\begin{tabular}{|c|l|c|c|}
\hline \multicolumn{2}{|c|}{ Statements } & \multicolumn{2}{|c|}{ Options } \\
\hline & \multicolumn{1}{|c|}{ Yes } & No \\
\hline 1. & $\begin{array}{l}\text { Provide new comers to the area with valuable } \\
\text { \& professional contacts }\end{array}$ & $87 \%$ & $13 \%$ \\
\hline 2. & $\begin{array}{l}\text { Give opportunity to members of Alumni } \\
\text { association to help each other. }\end{array}$ & $85 \%$ & $15 \%$ \\
\hline 3. & $\begin{array}{l}\text { Help to provide chances for leadership and } \\
\text { administrative qualities. }\end{array}$ & $81 \%$ & $19 \%$ \\
\hline 4. & $\begin{array}{l}\text { Involve more alumni in admission process to } \\
\text { keep university's diverse student makeup }\end{array}$ & $72 \%$ & $28 \%$ \\
\hline 5. & $\begin{array}{l}\text { Develop \& Promote programs to serve needs } \\
\text { and interests of students and university }\end{array}$ & $78 \%$ & $22 \%$ \\
\hline 6. & $\begin{array}{l}\text { Provide a helping hand to those who are } \\
\text { currently studying }\end{array}$ & $73 \%$ & $27 \%$ \\
\hline 7. & Helpful for the better help at working places & $72 \%$ & $28 \%$ \\
\hline 8. & $\begin{array}{l}\text { Give opportunity to be contact with educa- } \\
\text { tional institute even after completion of } \\
\text { education. }\end{array}$ & $81 \%$ & $19 \%$ \\
\hline
\end{tabular}

The above table shows that majority of the students think that alumni associations provide new comers to the area with valuable and professional contacts and they will able to help each others. It also helps to develop leadership and administrative qualities as well as promote program to serve needs and interest of students and university. It provides assistance to students in their studies and their working places even as well they get the opportunity to be in contact with their educational institute even after the completion of their education.

The visual representation is given through graph below.

The table shows that majority of the students think that alumni association provide platform to develop financial and other resources, assist university to maintain its integrity. It is also key to manage student related affairs outside class- room as well as students easily cope with future challenges share their knowledge, have information about market value of students and new trends in respective fields within and outside country, promote employment among students as well as they will be able to have life long association with their institute also.

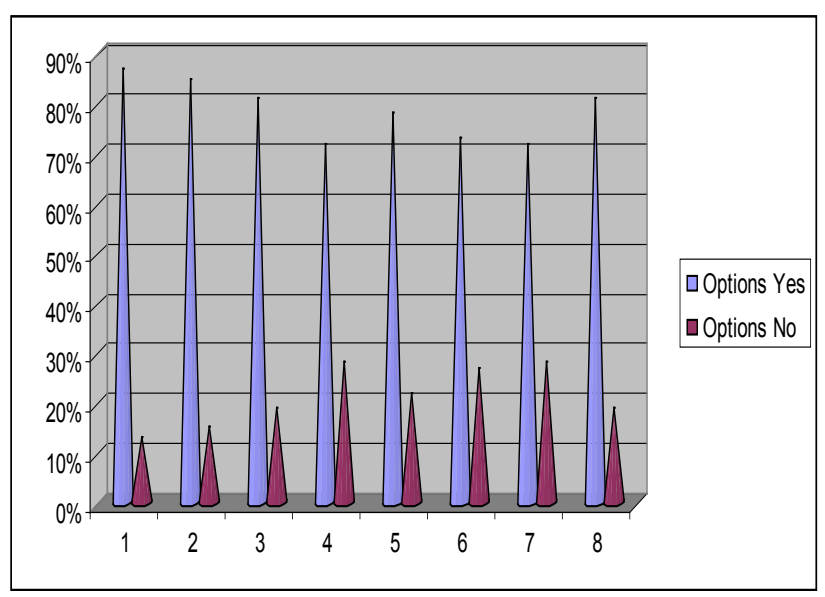

Table 2. shows the views of students about Alumni association, as its role in the promotion of university

\begin{tabular}{|c|l|c|c|}
\hline \multicolumn{2}{|c|}{ Statements } & \multicolumn{2}{c|}{ Options } \\
\hline & \multicolumn{1}{|c|}{ Yes } & No \\
\hline 1. & $\begin{array}{l}\text { Provide platform to develop financial and } \\
\text { other resources for the institute }\end{array}$ & $76 \%$ & $24 \%$ \\
\hline 2. & $\begin{array}{l}\text { Assist university to achieve prominence and } \\
\text { maintain its integrity }\end{array}$ & $78 \%$ & $22 \%$ \\
\hline 3. & $\begin{array}{l}\text { Key Portfolio to support and manage student } \\
\text { related affairs outside classroom }\end{array}$ & $75 \%$ & $25 \%$ \\
\hline 4. & $\begin{array}{l}\text { Provide guidance to cope up with the changes } \\
\text { and challenges of time }\end{array}$ & $81 \%$ & $19 \%$ \\
\hline 5. & $\begin{array}{l}\text { Give a forum through alumni association to } \\
\text { students to share their knowledge }\end{array}$ & $78 \%$ & $22 \%$ \\
\hline 6. & $\begin{array}{l}\text { Provide information about new trends and } \\
\text { respective fields within and outside country }\end{array}$ & $69 \%$ & $31 \%$ \\
\hline 7. & $\begin{array}{l}\text { Faster a long term association with students } \\
\text { and institute }\end{array}$ & $71 \%$ & $29 \%$ \\
\hline 8. & Promote employment among students & $78 \%$ & $22 \%$ \\
\hline 9. & $\begin{array}{l}\text { Provide information about market value of } \\
\text { students at any particular university }\end{array}$ & $79 \%$ & $21 \%$ \\
\hline
\end{tabular}

The visual representation is given through graph below.

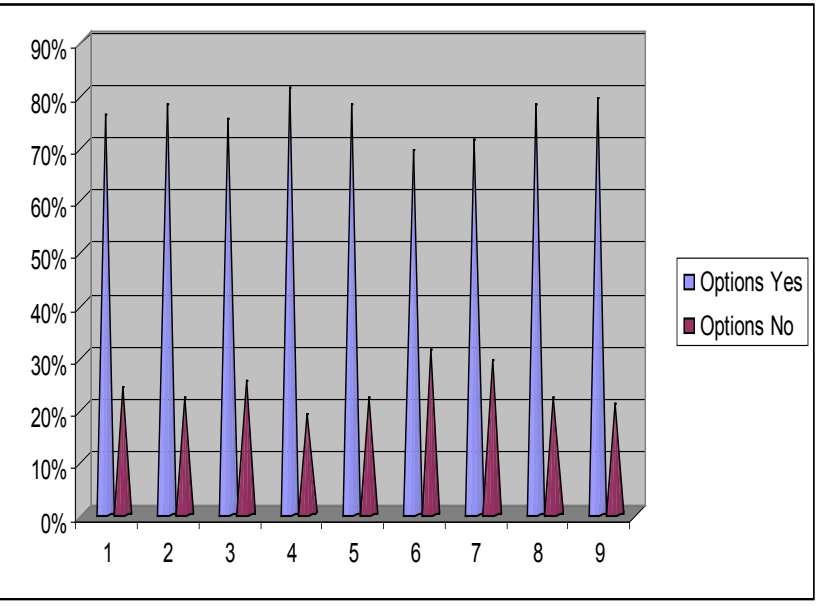


Table 3. shows the views of teachers about Alumni association, as its role in the progress of university

\begin{tabular}{|c|l|c|c|}
\hline \multicolumn{2}{|c|}{ Statements } & \multicolumn{2}{|c|}{ Options } \\
\hline 1. & $\begin{array}{l}\text { Alumni engage its members in the work of } \\
\text { university to serve Alumni Community in all } \\
\text { diversity }\end{array}$ & $85 \%$ & $15 \%$ \\
\hline 2. & $\begin{array}{l}\text { Assist the university in developing links with } \\
\text { professional }\end{array}$ & $85 \%$ & $15 \%$ \\
\hline 3. & $\begin{array}{l}\text { Assist a long life association between stu- } \\
\text { dents and institute through its program }\end{array}$ & $80 \%$ & $20 \%$ \\
\hline 4. & $\begin{array}{l}\text { Nourish traditions and growth of university } \\
\text { through welfare events of university }\end{array}$ & $80 \%$ & $20 \%$ \\
\hline 5. & $\begin{array}{l}\text { Provide platform as a best career advisor } \\
\text { network. }\end{array}$ & $70 \%$ & $30 \%$ \\
\hline 6. & $\begin{array}{l}\text { Give opportunity to student to volunteer their } \\
\text { time and expertise to support university }\end{array}$ & $85 \%$ & $15 \%$ \\
\hline 7. & $\begin{array}{l}\text { Play an integral role in maintaining the posi- } \\
\text { tion of university }\end{array}$ & $95 \%$ & $5 \%$ \\
\hline
\end{tabular}

The above table shows that majority of the teachers think that Alumni Association engages its members in the work of university to serve Alumni community in all diversity to develop link with professional. It also nourish traditions and growth of university through welfare events, provide platform as career advisor network, assist long life relations between students and university and assist in maintain position of university. It also gives opportunity to students to volunteer their time and expertise to support university.

The visual representation is given through graph below.

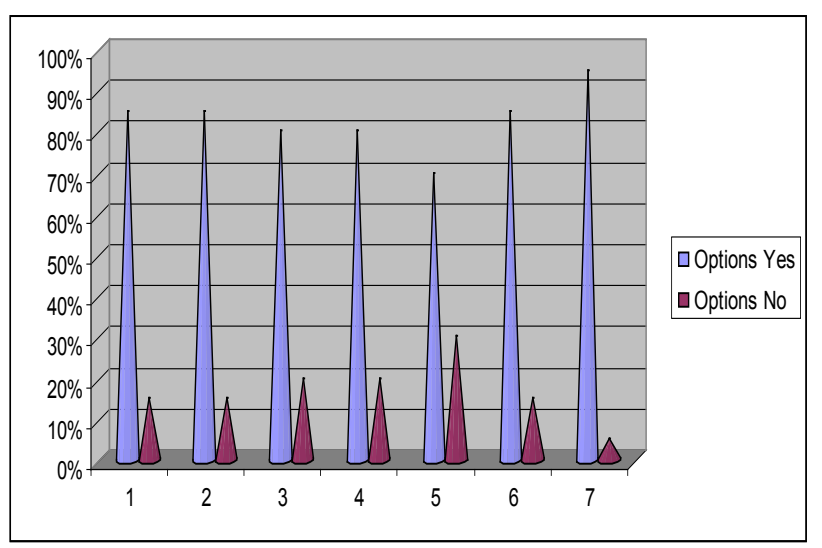

Table 4. shows the views of teachers about Alumni association, as its role beneficial for students

\begin{tabular}{|c|l|c|c|}
\hline \multicolumn{1}{|c|}{ Statements } & \multicolumn{2}{|c|}{ Options } \\
\hline & \multicolumn{1}{|c|}{ Yes } & No \\
\hline 1. & $\begin{array}{l}\text { Provide help for students to pave way to- } \\
\text { wards a bright future. }\end{array}$ & $75 \%$ & $25 \%$ \\
\hline 2. & $\begin{array}{l}\text { Create leadership and administrative qualities } \\
\text { among students }\end{array}$ & $70 \%$ & $30 \%$ \\
\hline 3. & $\begin{array}{l}\text { Assist graduates to create a reunion within or } \\
\text { outside institute }\end{array}$ & $80 \%$ & $20 \%$ \\
\hline 4. & $\begin{array}{l}\text { Help in eradicating unemployment from } \\
\text { society }\end{array}$ & $40 \%$ & $60 \%$ \\
\hline 5. & $\begin{array}{l}\text { Aware students about facilities available } \\
\text { within or outside country. }\end{array}$ & $65 \%$ & $35 \%$ \\
\hline 6. & $\begin{array}{l}\text { Promote interaction among Alumni and } \\
\text { newcomers for social and professional con- } \\
\text { tacts }\end{array}$ & $85 \%$ \\
\hline
\end{tabular}

The above table shows that majority of the teachers think that alumni associations provide help for student to pay their way towards a bright future create leadership and administrative qualities. It also assists graduates to create reunion, overcome unemployment from society and aware students about facilities available within and outside country as well as promote interaction among Alumni and newcomers for social and professional contacts. The visual representation is given through graph below.

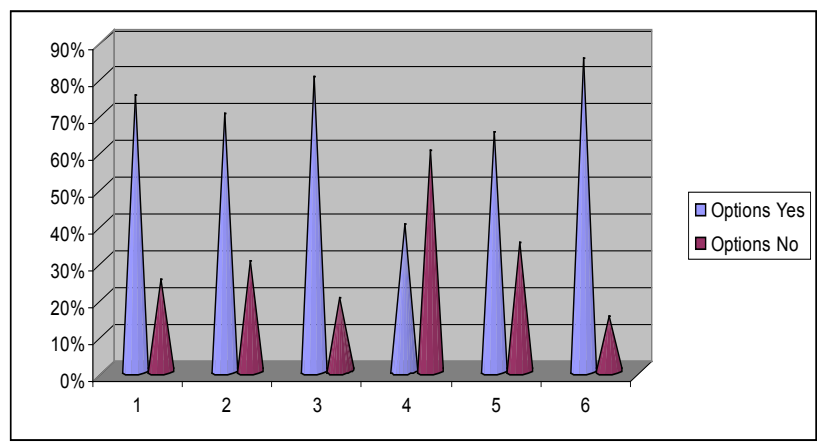

Table 5. shows the views of teachers about Alumni association, as its role in the administration of university

\begin{tabular}{|c|l|c|c|}
\hline \multicolumn{1}{|c|}{ Statements } & \multicolumn{2}{c|}{ Options } \\
\hline & \multicolumn{1}{|c|}{ Yes } & No \\
\hline 1. & $\begin{array}{l}\text { Involve in admission process to maintain and } \\
\text { expend diverse student makeup }\end{array}$ & $65 \%$ & $35 \%$ \\
\hline 2. & $\begin{array}{l}\text { Assist to develop financial and other re- } \\
\text { sources for institute }\end{array}$ & $75 \%$ & $25 \%$ \\
\hline 3. & $\begin{array}{l}\text { Support \& manage students related matters } \\
\text { outside the classroom }\end{array}$ & $65 \%$ & $35 \%$ \\
\hline 4. & $\begin{array}{l}\text { Provide guidance for students to face chal- } \\
\text { lenge and hindrances }\end{array}$ & $85 \%$ & $15 \%$ \\
\hline 5. & $\begin{array}{l}\text { Provide forum for students to share their } \\
\text { knowledge and aware about new trends in } \\
\text { society }\end{array}$ & $75 \%$ & $25 \%$ \\
\hline 6. & $\begin{array}{l}\text { Give information about market value of } \\
\text { concerned university }\end{array}$ & $75 \%$ & $25 \%$ \\
\hline
\end{tabular}

The above table shows that majority of the teachers think that alumni also involved in admission process to maintain and expand diverse student's makeup. It also develops financial and other resources for institute, support students related affairs outside the classrooms, provide guidance to students to face challenges and hindrances. It not only give forum for students to share their knowledge and aware of new trends in the society as well as provide teachers about market value of their university or institute.

The visual representation is given through graph below.

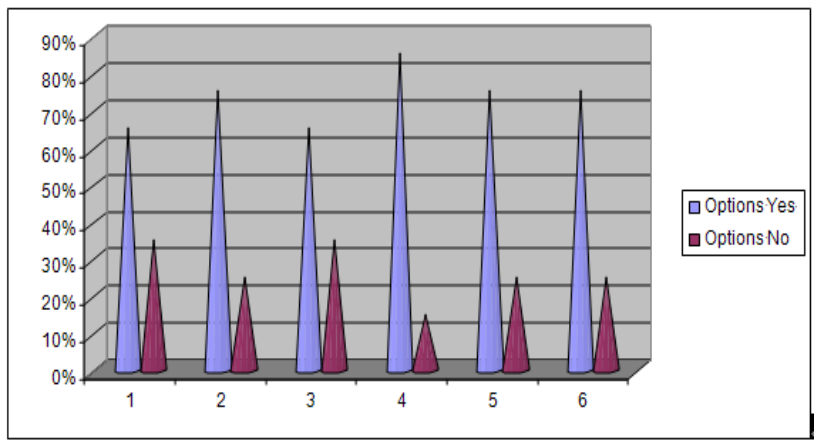




\section{Conclusions}

The results which are got by filling the questionnaires from both teachers and students clearly indicate the importance of Alumni Association at higher level within our country. As majority of them agree that such associations engage its members in the work of university to serve the alumni community in all its diversity as well as assist the university in developing links with professions. Not only this but alumnis at this level also provide new comers to the area with valuable contacts and platform as a best career advisor network to develop leadership and administrative qualities and provide opportunity for reunion with the students as well as to volunteer their time and expertise to support the reputation of university.

\section{Recommendations}

The important recommendations which carry out from this research study are:

1. Alumni association should be established at every private and public university as well as in departments also because it will give a plate form for the students to share their ideas, to develop leadership management and organizing qualities, chance for the outlet of their abilities and potentials.

2. Funds should be provided by the govt. to every university as to lead different programs by Alumni Association, by which various cultural, social, educational, vocational programs can be arranged at national and international level.

3. The universities should provide chances for the alumni of different universities to share their strength so they will come to know about the latest trends, issues and changes which take place in their respective fields other than their university.

4. Gatherings should be arranged by Alumni Association at this level as it helps the students to know the needs and difficulties of practical life and assist them to develop links with professional within or outside the country.

5. Administration of universities should encourage teachers to establish Alumni as it will provide a helping hand in conducting lecturer, seminars, workshops not only about career guidance but also related to concern fields.
6. It is the main aim of Alumni Association that it provides social and economical support and gives aid for the adjustments of individual, especially to students by eradicating unemployment from society.

7. It is necessary that the students should generate amounts instead of depending on others only and for this purpose, it makes sure that every alumnis pay some fixed amount as a member of this association.

\section{REFERENCES}

[1] V.C. Pandey (2005) High Education in a Globalizing World, Isha Books, Dehli, Pg 6.

[2] Dr. Captain Isani \& Muhammad Latif Virk (2003) Higher Education in Pakistan, Roshni Art Press, Islamabad, Pg 4.

[3] http://www.xaiver.edu/ sall

[4] http://www.haveford.edu/ Alumni relations

[5] http://aluni.jhu.edu/association/index.htm

[6] http://www.bu.edu/ alumni/int/connect/association.html

[7] http://www.clarku.edu/ alumni/association/strategic/plan.cfm

[8] http://www.hamdard.edu.pk/ alumni

[9] http://alumni.indiana.edu/ career/index.shtmp

[10] http://answer.yahoo.com/ question/index

[11] http://dictionary.sensagent.com

[12] http://www.alumni.mcGill.ca/ ?id=NZMZ

[13] http://www.queensu.ca/ alumni/programs/quaa.html

[14] http://en.wikipedia.org/wiki/ University-of-Cambridge

[15] http://www.urfaweb.ualberta.ca/ alumni/about.cfm

[16] http://www.alu.ak.alumni

[17] http://www.neduet.edu.pk8080/alumni/introduction.jsp

[18] http://www.hamdard.edu.pk.alumni/ 